\title{
Hvorfor skal pasienten medvirke i forskning?
}

\author{
Pasientmedvirkning er en sentral del av utformingen av helsepolitikken. I dag stilles det krav til pasientmed- \\ virkning også i forskningen. Pasienters og brukeres erfaringer skal anerkjennes og bidra til å skape praksis- \\ relevant kunnskap. I Forskningsrådets utlysninger må man begrunne hvorfor man eventuelt ikke velger å invol- \\ vere tjenestebrukere. Men hvordan påvirker brukermedvirkning forskningsprosessen?
}

\author{
Sidsel Natland \\ Sidsel-Therese.Natland@hioa.no \\ Sidsel Tveiten \\ Ingrid Ruud Knutsen
}

Brukermedvirkning ble innført som et sentralt statlig virkemiddel gjennom St.meld. nr. 41 (1987-88), Helsepolitikken mot år 2000. Nasjonal helseplan. Blant de helsepolitiske målene var økt demokratisering, brukerinnflytelse og rettssikkerhet. Spørsmål om hvordan tjenestene kunne utvikles til å møte pasienter med respekt og empati, ble fremhevet, og det ble økt behov for å innhente brukererfaringer. Dette bidro i sin tur til å anerkjenne brukererfaringer som verdifull kunnskap for helsetjenestene, inkludert pasienters subjektive kunnskap, deres perspektiv og virkelighetsforståelse. Innen medisin- og helseforskning kan dette bidra til å utfylle klinikerens og forskerens perspektiv. Dette har ført til nye former for kunnskapsproduksjon: deltagerbasert forskning, brukerinvolvert forskning, medforskning, samarbeidsforskning, brukerstyrt forskning. Fra å forske på eller om pasienter, forsker man sammen (1).

Vi opplever imidlertid at det er behov for å drøfte hva denne formen for kunnskapsproduksjon innebærer på et vitenskapsteoretisk nivå. Vi vil derfor innledningsvis belyse noen syn på hvor og hvordan slik kunnskap produseres. Deretter drøfter vi hvordan brukermedvirkning kan påvirke kunnskapsproduksjonen.

\section{Brukermedvirkning og forskning}

Medvirkning kan graderes på en skala der laveste nivå er konsultasjon: Brukerne blir spurt, man rådfører seg om hva de synes er viktig å forske på, uten at det nødvendigvis tas til følge. Neste trinn er samarbeid. Det kan ta mange former, fra medlem i styringsgrupper til samarbeid om selve forskningen, og kan involvere én eller flere, alt etter hva man blir enige om og har kompetanse på. Det høyeste nivået er brukerkontrollert forskning: Brukerne bestemmer forsknings- tema og tilnærming. Dette er omstridt, blant annet knyttet til spørsmål om det innebærer at brukerne skal gjøre alt selv, eller om de kan få profesjonelle forskere til å utføre selve forskningen.

Brukermedvirkning i forskning knyttes gjerne til deltagende former for forskning der problemstillinger og formål vokser frem «innenfra». Det kan være praksisforskning - for eksempel med utgangspunkt i klinikeres behov for kunnskap om sin praksishverdag, eller det kan være aksjonsforskning. Aksjonsforskning kjennetegnes av enighet blant deltagerne om at de ønsker endring, og at man vil forske sammen for å produsere viten om verden, men også for å forandre den.

Innen forskningen har det imidlertid blitt diskutert hvordan brukermedvirkningen påvirker den vitenskapelige forskningsprosessen. Diskusjonene berører spørsmål om kunnskapen som produseres, er gyldig når pasienter og brukere skal medvirke samt om denne forskningstilnærmingen passer for alle disipliner og prosjekter. For å forstå hvilken verdi brukerperspektivet kan ha for kunnskapsproduksjon, må vi se til vitenskapshistorien og hvordan synet på kunnskap har endret seg.

\section{Fra elfenbenstårnet til markedsplassen}

I industrisamfunnet var målet å finne frem til evig gyldige sannheter som kunne forklare verdens innretning og sammenhenger. Teori og praksis var atskilte sfærer. Forskningens oppgave var å produsere kunnskap som andre kunne omsette i praksis. Selve kunnskapsproduksjonen ble betraktet som en opphøyd aktivitet; forskerne forsket fritt og uavhengig for erkjennelsens egen skyld.

Vår tid betegnes som kunnskapssamfunnet og kjennetegnes av globalisering, kompleksitet og usikkerhet. Vitenskapen har ikke lenger ubetinget legitimitet til å definere «den sanne viten». Samfunnet stiller $ø k t e$ krav om at kunnskapen som produseres, er orientert mot anvendelse og konkret nytteverdi.

Gjennom denne dreiningen endres forholdet mellom samfunn og vitenskap, og den tradisjonelt skarpe grensen forrykkes. Vitenskapsteoretisk har diskusjonene handlet om hva vi skal regne som nyttig kunnskap, og hvor og hvordan kunnskap skal produseres. Samfunnsforskerne Nowotny, Gibbons og Scotts argumenterte i boken Re-thinking science - knowledge and the public in an age of uncertainty (2) for en ny forståelse av kunnskapsproduksjon som innebar at forskerne måtte forlate «elfenbenstårnet» og lytte mer til omgivelsene. Det krever anerkjennelse av at kunnskap produseres på flere arenaer enn i akademia. Dette betegner de som en bevegelse fra modus 1- til modus 2-samfunnet, der modus 2-kunnskap har fått større innflytelse og tillegges mer vekt.

Modus 1 innebærer en kunnskapsforståelse der teori og praksis er atskilte sfærer; forskningen foregår innenfor et relativt lukket miljø der legitimitet oppnås fra eget forskerfellesskap. Forskningens oppgave er å produsere kunnskap som praktikere kan omsette. Randomiserte, kontrollerte studier av legemidlers effekt kan være et eksempel på dette.

Modus 2 innebærer en ny form for kunnskapsproduksjon der klinikere, pasienter, pårørende, ledere osv. involveres i forskningsprosessen. Fra å være objekt for forskning kan pasienten bli medforsker i team der man sammen formulerer forskningsprosjektets mål og metoder. Det anvendte siktemålet blir tydelig. Forskningsresultatene kan diskuteres av og med ulike parter med ulike kompetanser, interesser og perspektiver. Denne modellen vektlegger tverrfaglighet, samarbeid og en gitt kontekst.

På den annen side har modus 2 implikasjoner for hvordan kunnskapen kan kvalitetskontrolleres. Når kunnskapen skapes i samarbeid mellom forskere og aktører i feltet, er det ikke lenger gitt at det er forskernes tradisjonelle fagfellesskap som skal vurdere kvaliteten. Når forskningen produseres $i$ andre kontekster og med andre deltagere, er ikke tradisjonelle kvalitetsmål nødvendigvis brukbare eller relevante. Vil dette redusere forskningens pålitelighet?

Nowotny og medarbeidere mener ikke det. De snakker heller om «sosialt robust 


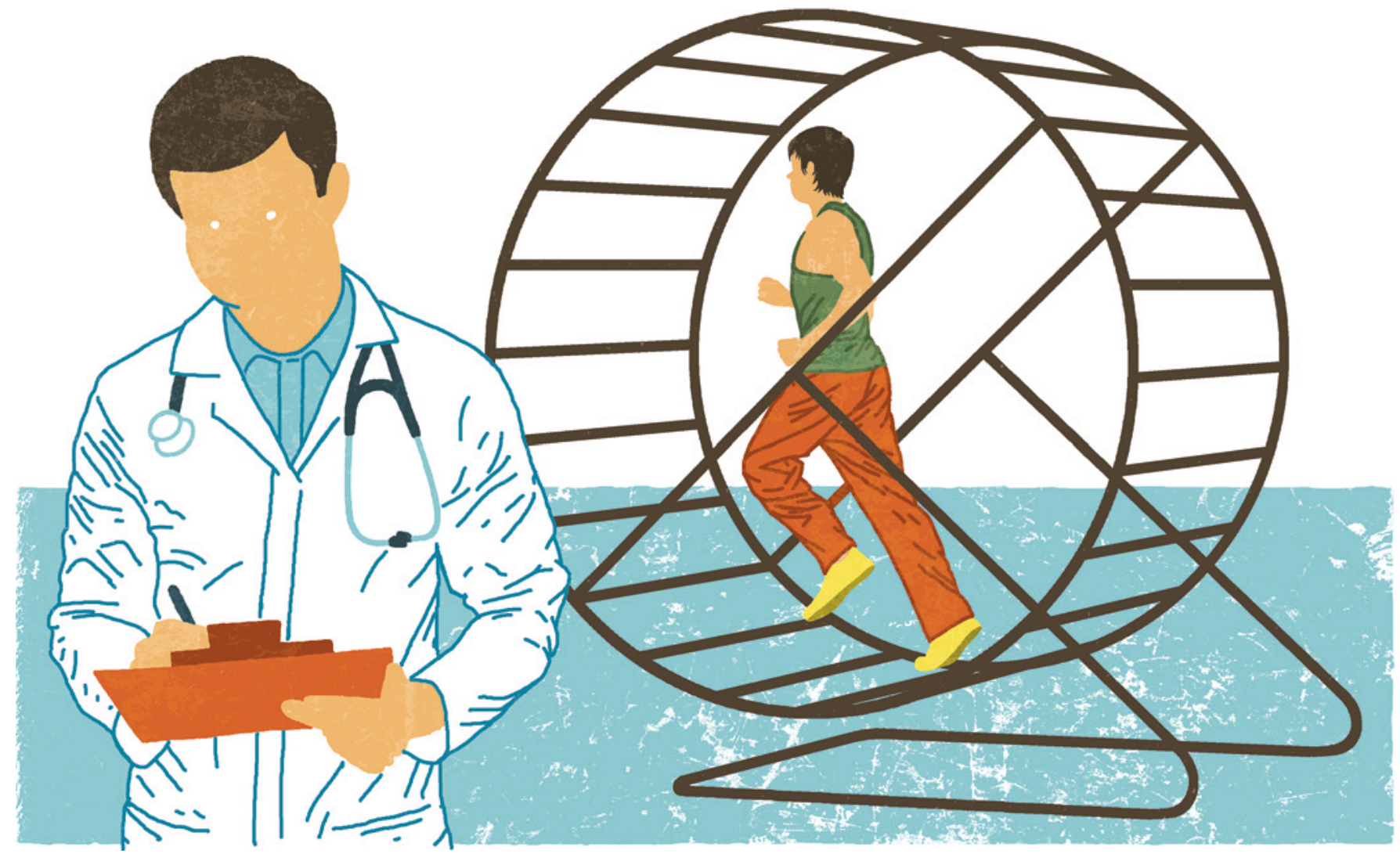

Illustrasjon: Ørjan Jensen/Superpop

kunnskap». De mener at slik kunnskap vil ha større gjennomslagskraft nettopp fordi den produseres i samarbeid med andre, og fordi den diskuteres i offentligheten - på det de kaller «markedsplassen» (2).

Innføringen av modus 2-kunnskap kan imidlertid ikke bety at modus 1-kunnskap skal forkastes. Vi vil peke på betydningen av at begge typer kunnskap finnes innen medisinsk og helsefaglig forskning. Samtidig kan økt bevissthet om vitenskapsteoretisk ståsted åpne opp for nye muligheter knyttet til forskningsdesign og hvordan pasientmedvirkning kan gjennomføres.

\section{Brukermedvirkningens bidrag til kunnskapsproduksjon}

Mye forskning $(1,3-8)$ peker på fordeler med brukermedvirkning, ikke minst tilgangen til en kunnskap som forskningsmiljøene ikke nødvendigvis har, f.eks. pasienters førstehåndserfaringer. En slik subjektorientering kan øke forskningens relevans. Brukermedvirkning knyttes også til myndiggjøring (empowerment). Det at brukernes stemme anerkjennes også i kunnskapsproduksjon, kan ha en styrkende effekt på dem.

Samtidig finnes det utfordringer. Forskere, klinikere og ledere kan være ubekvemme med å gi fra seg eller dele makt og innflytelse i samarbeidsprosjekter, noe som kan resul- tere $\mathrm{i}$ at brukere settes på sidelinjen og ikke får delta i viktige beslutninger om prosjektet (3). Andre utfordringer kan være forventninger, tid og ressurser. Brukere kan ha urealistiske forventninger om hva som skal komme ut av forskningen. Prosjektene er ressurskrevende i form av tid og penger. Slike forhold må diskuteres åpent $\mathrm{i}$ prosjektenes startfase. Formålet med denne kronikken er imidlertid å fokusere på pasientmedvirkningens muligheter og utfordringer for den vitenskapelige prosessen og kunnskapsproduksjonen. Vi vil nevne forskningens kvalitet, representativitet og eventuelle skjevheter.

En vesentlig påvirkning er hvordan pasientmedvirkning innebærer muligheten for å lære «fra innsiden». Men da må innside-kunnskapen betraktes og anvendes som noe mer enn bare enkelthistorier. Pasientkunnskapen kan ha potensial for justering av formål, problemstillinger og gjennomføring av forskning. Epistemiske kulturer må utfordres.

En fallgruve er imidlertid å forutsette at pasienten som forteller sin erfaring, også forstår den - at beskrivelse forutsetter forståelse. Dette kan også skje om forskerne ikke stiller kritiske spørsmål ved pasientens fortelling eller ikke setter den inn i en større sosial kontekst, fordi man er redd for at det kan oppfattes som å ikke anerkjenne eller tro på den. Men forskeren kan ikke se bort fra sosiale, kulturelle og politiske forhold som omkranser brukerens virkelighetsforståelse det ville være å miste viktig kontekstuell informasjon og muligheten til å se pasientkunnskapen i et bredere perspektiv (4).

Det hevdes gjerne at brukermedvirkning kan styrke dataenes kvalitet. I kvalitative intervjuprosjekter fremheves hvordan informanter forteller mer når brukere intervjuer brukere, fordi de opplever jevnere maktforhold i intervjusettingen (5). Forskningsresultatene kan også bli annerledes enn når forskningen kun utføres av tradisjonelle forskere, for eksempel kan den oppleves mer relevant for praktikere og brukere.

En utfordring er imidlertid spørsmålet om representativitet - hvem er brukeren representativ for? Hvilke pasienter er det som melder sin interesse for å delta som medforskere? Det understreker et viktig poeng, nemlig at anerkjennelse av pasienterfaringer ikke må føre til at man ukritisk gir personlig innside-kunnskap en særlig posisjon. Å anse én pasients fortelling som representativ for en pasientgruppe kan bidra til ny homogenisering - og bidra til at kompleksitet, ulike identiteter og relasjoner underkommuniseres, med fare for en ny form for «essensialisme».

Brukere kan ha sin egen agenda og selv 
bidra til generalisering ut fra egne opplevelser. Subjektiv erfaringskunnskap kan bestå av høyst varierende erfaringer. Dette kan skape skjevheter i kunnskapsgrunnlaget. Med andre ord kan brukermedvirkningens styrke - anerkjennelsen av individuelle brukererfaringer - også være en utfordring for den vitenskapelige prosessen. En løsning kan være å tenke annerledes om hvor brukeren skal delta, og om hvor mye personlig erfaring han/hun må ha om det konkrete forskningstemaet. Brukerrepresentanten kan for eksempel delta i forskning på andre steder enn den institusjon han/hun selv har vært pasient ved (4).

Det kan også innvendes at brukerne ikke har kunnskap og ferdigheter om forskningsprosessens vitenskapelige prosedyrer. I flere land har man derfor utviklet egne kurs for brukere som trenger økt kompetanse (6). Men dette kan også kobles til spørsmålet om representativitet - utvikler da brukeren seg til å bli mer konvergent med klinikerens og forskerens ståsted? Er da brukermedvirkningen reell?

\section{Å balansere på en linje mellom disiplinkrav og kreativitet}

I utviklingen av forskningsdesign vil synet på brukeren og grad av involvering, påvirkes av forskernes vitenskapsteoretiske ståsted. Aksjonsforskere og en del praksisforskere vil gjerne utvikle prosjekter der pasienter medvirker på høyt nivå og som medforskere. Forskningsprosjekter der man kun ønsker å konsultere brukere, vil fortsette å være forsker- og/eller klinikerstyrte.

For å møte kravene om brukermedvirkning i forskning må vi imidlertid være åpne for spørsmål og innvendinger. Er brukermedvirkning alltid gjennomførbart? Innen medisin som forskningsdisiplin utføres forskning som er fjernere og mer løsrevet fra brukernes hverdag, som biomedisinsk og laboratoriebasert forskning. Randomiserte, kontrollerte designer er også av høy relevans for kunnskapsproduksjonen på dette feltet. Denne forskningen har sin forankring i positivistiske vitenskapsidealer som kanskje ikke like lett lar seg forene med tidens trender om fremforhandlet modus 2-kunnskap. Ikke desto mindre har forskere ved University of Glasgow utviklet standardprosedyrer for hvordan pasienter kan medvirke i alle deler av randomiserte studier (7), og det er blitt argumentert for at flere utfall enn statistisk krav om primærutfall kunne få høyere status, for eksempel hvis data indikerer andre og uintenderte effekter som kan være betydningsfulle for brukere (8).

Det er enighet om at pasientperspektivet bidrar til å komplettere klinikerens og forskerens perspektiv. Pasientmedvirkning kan ikke kun betraktes som et alibi, men som likeverdig i kunnskapsproduksjon for å forske frem bedre tjenester og helsetilbud. Vi har her poengtert at medvirkning kan graderes, og det er kun de høyeste nivåene som innebærer medforskning. Det må være rom for varierte tilnærminger i forskningen; ulike faser av prosjektet kan passe for henholdsvis å konsultere og å samarbeide (eller til og med å styre).

Økt bevissthet om brukermedvirkningens mange former kan bidra til at forskere ser nye muligheter for pasientmedvirkning i kunnskapsproduksjonen. Om man gjør seg kjent $\mathrm{i}$ terrenget, kan mye åpenbare seg på veien fra elfenbenstårnet til markedsplassen.

\section{Sidsel Natland (f. 1972)}

er førsteamanuensis ved Institutt for sosialfag, Fakultet for samfunnsvitenskap, Høgskolen i Oslo og Akershus. dr.art. i kulturvitenskap fra Universitetet i Bergen. Hun har erfaring fra praksisforskning og deltakerbaserte forsknings- og utviklingsprosjekter innen sosialt arbeids praksis og utdanning.

Forfatter har fylt ut ICMJE-skjemaet og oppgir ingen interessekonflikter.

\section{Sidsel Tveiten (f. 1953)}

er professor ved Institutt for sykepleie og helsefremmende arbeid, Høgskolen i Oslo og Akershus. Hun er utdannet sykepleier, er sykepleielærer og ph.d. fra Det medisinske fakultet, Institutt for sykepleievitenskap, Universitetet i Oslo og har erfaring med bruker som medforsker gjennom hele forskningsprosessen, fra idé til publisert manus.

Forfatter har fylt ut ICMJE-skjemaet og oppgir ingen interessekonflikter.

\section{Ingrid Ruud Knutsen (f. 1967)}

er førsteamanuensis ved Institutt for sykepleie og helsefremmende arbeid ved Høgskolen i Oslo og Akershus. Hun er utdannet sykepleier og ph.d. fra Det medisinske fakultet, Institutt for helse og samfunn, Universitetet i Oslo. Forfatter har fylt ut ICMJE-skjemaet og oppgir ingen interessekonflikter.

Litteratur

1. Beresford P. User Involvement in Research and Evaluation: Liberation or Regulation? Soc Policy Soc 2002; 1: 95-105.

2. Nowotny O, Gibbons M, Scotts P. Re-thinking science - knowledge and the public in an age of uncertainty. Cambridge: Polity Press, 2001.

3. Natland S, Hansen R. Conflicts and empowerment - a processual perspective on the development of a partnership. European Journal of Social Work 2016. www.tandfonline.com/doi/full/10.1080/ 13691457.2016.1207615 (4.10.2106).

4. McLaughlin $\mathrm{H}$. Keeping service user involvement in research honest. Br J Soc Work 2010; 40: 1591-608.

5. Johannessen A, Natland S, Støkken AM. red. Samarbeid i praksis. Erfaringer fra HUSK-prosjektet. Oslo: Universitetsforlaget, 2011

6. Boote J, Telford R, Cooper C. Consumer involvement in health research: a review and research agenda. Health Policy 2002; 61: 213-36.

7. Evans BA, Bedson E, Bell P et al: West Wales Organisation for Rigorous Trials in Health (WWORTH). Involving service users in trials: developing a standard operating procedure. Trials 2013; 14: 219.

8. Rose D. Service user produced knowledge. J Ment Health 2008; 17: 447-51.

Mottatt 4.10. 2016, første revisjon innsendt 17.11. 2016 og godkjent 22.12. 2016. Redaktør: Ketil Slagstad. 